\title{
A Review on Membranes and Catalysts for Anion Exchange Membrane Water Electrolysis Single Cells
}

\author{
Min Kyung Cho ${ }^{1}$, Ahyoun Lim ${ }^{1,2}$, So Young Lee ${ }^{1}$, Hyoung-Juhn Kim ${ }^{1,3}$, Sung Jong Yoo,3, \\ Yung-Eun Sung ${ }^{2,5}$, Hyun S. Park ${ }^{1, * *}$, and Jong Hyun Jang ${ }^{1,3,4, *}$ \\ ${ }^{1}$ Fuel Cell Research Center, Korea Institute of Science and Technology (KIST), Seoul 02792, Republic of Korea \\ ${ }^{2}$ School of Chemical and Biological Engineering, Seoul National University, Seoul 08826, Republic of Korea \\ ${ }^{3}$ Division of Energy \& Environment Technology, KIST School, Korea University of Science and Technology, Seoul 02792, \\ Republic of Korea \\ ${ }^{4}$ Green School, Korea University, Seoul 02841, Republic of Korea \\ ${ }^{5}$ Center for Nanoparticle Research, Institute for Basic Science (IBS), Seoul 08826, Republic of Korea
}

\begin{abstract}
The research efforts directed at advancing water electrolysis technology continue to intensify together with the increasing interest in hydrogen as an alternative source of energy to fossil fuels. Among the various water electrolysis systems reported to date, systems employing a solid polymer electrolyte membrane are known to display both improved safety and efficiency as a result of enhanced separation of products: hydrogen and oxygen. Conducting water electrolysis in an alkaline medium lowers the system cost by allowing non-platinum group metals to be used as catalysts for the complex multi-electron transfer reactions involved in water electrolysis, namely the hydrogen and oxygen evolution reactions (HER and OER, respectively). We briefly review the anion exchange membranes (AEMs) and electrocatalysts developed and applied thus far in alkaline AEM water electrolysis (AEMWE) devices. Testing the developed components in AEMWE cells is a key step in maximizing the device performance since cell performance depends strongly on the structure of the electrodes containing the HER and OER catalysts and the polymer membrane under specific cell operating conditions. In this review, we discuss the properties of reported AEMs that have been used to fabricate membrane-electrode assemblies for AEMWE cells, including membranes based on polysulfone, poly(2,6-dimethyl-p-phylene) oxide, polybenzimidazole, and inorganic composite materials. The activities and stabilities of tertiary metal oxides, metal carbon composites, and ultra-low Pt-loading electrodes toward OER and HER in AEMWE cells are also described.
\end{abstract}

Keywords : Water electrolysis, Anion exchange membrane, Electrocatalyst, Membrane electrode assembly, Single cell

Received : 25 May 2017, Accepted : 5 July 2017

\section{Introduction}

Greenhouse gas (GHG) emissions arising from fossil fuel combustion present a serious problem that is having an increasing and unprecedented impact on the global environment [1]. Together with the accumulation of carbon dioxide in the atmosphere, GHG emissions are the main cause of global warming and climate change [2]. The atmospheric levels of carbon

*E-mail address: *jhjang@kist.re.kr, **hspark@kist.re.kr DOI: https://doi.org/10.5229/JECST.2017.8.3.183 dioxide have exceeded 400 ppm as of February 2017 and are expected to reach approximately $530 \mathrm{ppm}$ by 2050 [3]. As a consequence of the increased GHG accumulation in the atmosphere, the global aver'age temperature is estimated to increase by more than $3^{\circ} \mathrm{C}$ by 2050 , which will cause unavoidable climate change and have considerable economic and social impacts [4]. In order to mitigate the effects of fossil fuel consumption and GHG emissions, research aimed at developing technologies that utilize alternative and carbon-free energy resources has been rapidly intensifying for the last few decades [5]. 


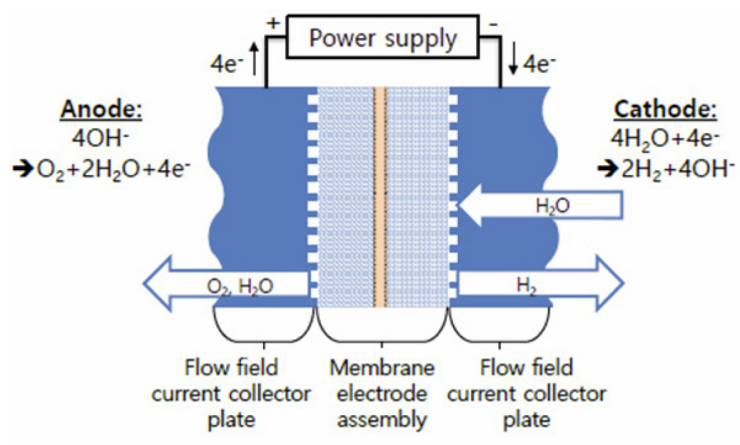

Anion exchange membrane water electrolysis

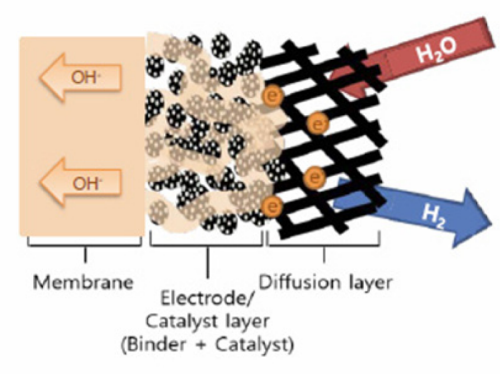

Membrane electrode assembly

Fig. 1. A schematic illustration of an AEMWE cell and a membrane electrode assembly.

As the most abundant energy carrier in the universe, hydrogen is considered to be a promising replacement for fossil fuels as a result of its non-toxicity, high mass energy density $\left(39.4 \mathrm{kWh} \mathrm{kg}^{-1}\right)$ [6], and high energy efficiency (>70\%) [7]. However, the majority of hydrogen produced commercially, i.e., more than 40 million metric tons per year, is currently produced from industrial steam reforming processes [8]. Hydrogen production using natural gases still emits a significant amount of $\mathrm{CO}_{2}$ (more than 300 million tons each year), which makes it difficult to employ this process as a sustainable hydrogen production technology [9]. Many other technologies have been investigated to date in an attempt to realize carbon-free production of hydrogen on an industrial scale such as thermolysis, photocatalysis, biomass gasification, and electrolysis [10].

Among the various hydrogen production methods, electrochemical water splitting employing renewable power sources is considered as a particularly feasible technology for the production of hydrogen without GHG emissions [7]. Nicholson and Carlisle first reported the water splitting phenomenon in 1800 and it has since been actively developed for industrial hydrogen production [11]. In this technology, a conventional electrolyzer uses a porous diaphragm that separates the anode and cathode in an alkaline solution $[7,12]$. The glass diaphragm conducts ions whilst also separating the produced hydrogen and oxygen into different chambers. Water electrolyzers based on liquid electrolytes are already being used commercially to produce highly purified and pressurized hydrogen [13]. Recent research on electrolyzer technology, however, has been focused on developing a system based on a solid polymer electrolyte membrane, in line with the advancements achieved in the field of polymer electrolyte membranes [13]. An electrolyzer based on a solid polymer electrolyte membrane consists of a membrane electrode assembly (MEA), with electrodes located on both sides of the electrolyte membrane, as illustrated in Fig. 1. Polymer electrolyte membrane water electrolysis provides several advantages when compared to the use of the porous diaphragm electrolyzer, including improved operational efficiency and safety and facile gas separation [14].

Polymer electrolyte membrane based electrolysis systems are classified into proton exchange membrane water electrolysis (PEMWE) and anion exchange membrane water electrolysis (AEMWE) depending on the types of ions conducted through the polymer membrane. PEMWE exhibits greater hydrogen production energy efficiency compared to AEMWE owing to the high conductivity of the employed electrolyte membrane [15]. However, PEMWE requires the use of expensive noble catalysts such as iridium and ruthenium oxides in order to facilitate the catalysis of the oxygen evolution reaction (OER) in corrosive acid electrolytes [16]. By contrast, performing water electrolysis under alkaline conditions allows non-noble metal oxides such as cobalt and nickel derivatives to be used as the water oxidation catalyst as a result of their favorable OER activities in basic solutions. This possibility represents a great advantage of AEMWE relative to PEMWE and can significantly reduce the associated costs [12,17]. It should be noted that as of March 2017 , the material costs of cobalt $(\$ 0.05 / \mathrm{g})$ and 
nickel $(\$ 0.01 / \mathrm{g})[18]$ are significantly lower than those of $\operatorname{Ir}(\$ 24 / \mathrm{g})$ and $\mathrm{Ru}(\$ 1.3 / \mathrm{g})$ [18]. However, the highest operational current density reported for AEMWE at $50^{\circ} \mathrm{C}$ using $\mathrm{IrO}_{2}$ as the OER catalyst (approximately $0.5 \mathrm{~A} \mathrm{~cm}^{-2}$ at $1.8 \mathrm{~V}$ ) [19] is considerably lower than that reported for PEMWE at $50^{\circ} \mathrm{C}$ using $\mathrm{IrO}_{2}$ as the OER catalyst $\left(0.9 \mathrm{~A} \mathrm{~cm}^{-2}\right.$ at $\left.1.8 \mathrm{~V}\right)$ [20]. It is clear, therefore, that there remains a significant room for improvement in the performance of AEMWE [21] in order to achieve operational current density comparable with PEMWE.

In order to improve the cell performance of AEMWE, anion exchange membranes (AEMs) with higher conductivity and water electrolysis catalysts with higher activity must be employed in the MEA and the cell operating conditions must be optimized. AEM development [21-50] has focused on controlling the membrane morphology and functionalization with various cationic groups in an attempt to attain excellent thermal and mechanical properties along with improved hydroxide conductivity $(\geq 0.1$ $\mathrm{S} \mathrm{cm}{ }^{-1}$ ) [51]. Most of the developed AEMs were employed in fuel cell applications $[25,26,30,32$, $35,40,42-45,47]$, with only a few AEMs used in water electrolysis cell tests [21,50]. The AEMs used in fuel-cell applications can also be used in water electrolysis applications. However, the performance of such AEMs should be confirmed in a water electrolysis configuration since the cell performance is highly dependent on the cell operating conditions. OER [52-62] and hydrogen evolution reaction (HER) [56,57,63-74] catalysts have also been developed actively for alkaline water electrolysis with the aim of achieving high catalytic activity and chemical stability under alkaline conditions. These developments have focused predominantly on controlling the crystalline structure and morphology of the catalysts and testing various transition metals or their oxides [75]. However, only a few of the developed catalysts have been tested in a full cell configuration $[52,63]$. The full cell test is essential because the promising properties and performances of newly developed materials must be confirmed in an MEA configuration for single cell performance validation. Therefore, along with enhancing the system components, optimizing the MEA configuration is also of significant importance in order to fully utilize the functionality of the cell components [76].
MEAs for AEMWE are composed of anion conducting polymer electrolyte membranes, with catalyst layers and diffusion layers located on both sides of the membrane. Hydroxide ions are produced by the HER at the cathode, subsequently transported from the cathode to the anode through the membrane, and finally oxidized into oxygen gas, water, and electrons [19]. To obtain high performance AEMWE, MEA optimization should be performed in tandem with material development so as to achieve facile electrochemical reactions. For example, extensive research has been conducted to optimize the MEA performance in PEM fuel cells, with many variables investigated such as the ionomer content in the catalyst layer [77-80], the catalyst layer structure [81-83], and the pressing conditions in the MEA fabrication process [84-87].

As discussed above, evaluating the performance of all developed materials in a single cell test is essential for real applications. However, only a few studies on materials developed for AEMWE have proven experimentally their performance in a single cell configuration. Single cell tests or device investigations serve as a direct and efficient tool for the examination of the developed electrode components (e.g., catalysts and membranes), given that there are various factors within the MEA that can influence cell performance under various operating conditions [88]. Through testing the cell operation in two-electrode devices, the relationship between device performance and component properties can be determined. Moreover, the performance in an actual device can be significantly different from that established at the component level since the full cell reactions involve complex ion and mass transport phenomena in the MEA. In addition, certain aspects of device performance can only be assessed by conducting research at the device level. For example, the performance degradation of water electrolysis cells caused by catalyst particle loss or membrane decomposition in the MEA can only be determined through single cell tests [88].

In this review, we focus on studies whose scope of investigation includes AEMWE cell tests where the electrode components were developed and applied to actual water splitting devices. First, we introduce AEMs that have been developed and used to fabricate MEAs, which have in turn been subsequently tested in AEMWE single cells under alkaline operat- 
ing conditions. AEMs with high ionic conductivities and chemical stabilities have been synthesized using polysulfone (PSF) [89,90], poly(2,6-dimethyl- $p$ phylene) oxide (PPO) [91], polybenzimidazole (PBI) [50,92], and inorganic composite materials [21]. Secondly, we review AEMWE single cell tests performed with non-platinum group metals (nonPGMs), ultra-low loading PGMs, or carbon composite catalysts for the OER and HER [52,93-95]. We have summarized the AEMWE studies that have conducted single cell tests with the developed materials in order to provide ideas on the testing of newly developed materials in a single cell configuration for maximized cell performance.

\section{AEMWE Membranes Tested in a Single Cell Configuration}

To achieve AEMWE with a high current density and good long-term operation, the AEM must exhibit high hydroxide conductivity in water and suitable chemical and mechanical stabilities, including a low fuel/product crossover and high dimensional stability (membrane swelling) under high $\mathrm{pH}$ conditions [51]. AEMs with a high ionic conductivity are produced by controlling the ion exchange capacity (IEC $[\mathrm{eq} / \mathrm{g}]$ ), which is correlated with the number of cationic groups attached to the polymer chain backbone. Many researchers have developed various types of AEMs, including homogeneous [50,89-92] and heterogeneous $[21,96]$ AEMs, in an attempt to improve the long-term stability of these membranes under basic conditions. The developed AEMs should be prepared as MEAs and examined in single cell configuration in order to ensure that their superior properties actually result in improved AEMWE cell performance and durability. Fig. 2 shows the chemical structure of three different AEM backbones: PSF, PPO, and PBI. In this section, we summarize the various AEMs that have been developed to date and their properties and performances in AEMWE single cells.

(a)

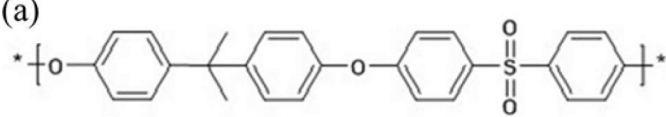

\subsection{Polysulfone-based AEMs}

PSF-based membranes possess several properties that are advantages for AEMWE applications, namely, they are chemically and mechanically stable under highly basic conditions [97] and they are also inexpensive and easy to synthesize. Xiao et al. conducted an AEMWE cell test using a self-cross-linking quaternary ammonia polysulfone (xQAPS) AEM and non-noble metal based electrodes [89]. The Xiao group developed the xQAPS based membrane in the previous study and observed only $3 \%$ swelling at $90^{\circ} \mathrm{C}$ while maintaining an effective $\mathrm{OH}^{-}$mobility ( 15 and $43 \mathrm{mS} \mathrm{cm}^{-2}$ at 20 and $90^{\circ} \mathrm{C}$, respectively) in liquid water after self-cross-linking [98]. MEAs for the OER and HER were fabricated by pressing the self-cross-linking xQAPS membrane between $\mathrm{Ni} / \mathrm{Fe}-$ coated $\mathrm{Ni}$ foam and $\mathrm{Ni} / \mathrm{Mo}$-coated stainless steel fiber felt, respectively, at $80^{\circ} \mathrm{C}$ for $2 \mathrm{~min}$ at a pressure of $2 \mathrm{MPa}$, and were subsequently tested in an AEMWE cell configuration [89]. The cell exhibited a water splitting current density of approximately $250 \mathrm{~mA} \mathrm{~cm}^{-2}$ at $1.8 \mathrm{~V}$ and $70^{\circ} \mathrm{C}$. Moreover, the voltage was stable at approximately $1.8 \mathrm{~V}$ over $8 \mathrm{~h}$ of constant current density operation at approximately $400 \mathrm{~mA} \mathrm{~cm}^{-2}$, with only a $<3 \%$ increase in voltage over this period. The authors expected that the MEA performance could be further improved by reducing the membrane/electrode contact resistance and by using a better cathode catalyst [89].

Parrondo et al. studied the MEA performance of PSF-based AEMs during AEMWE cell operation and analyzed the mechanism of AEM degradation. The AEMs were functionalized with different groups: quaternary benzyl trimethylammonium (PSF-TMA ${ }^{+} \mathrm{OH}^{-}$), quaternary benzyl quinuclidum $\left(\mathrm{PSF}-\mathrm{ABCO}^{+} \mathrm{OH}^{-}\right)$, and quaternary benzyl 1 methylimidazolium (PSF-1 $\mathrm{M}^{+} \mathrm{OH}^{-}$) [90]. The ionic conductivities of PSF-TMA ${ }^{+} \mathrm{OH}^{-}$, PSF-ABCO $\mathrm{OH}^{-}$, and PSF- $1 \mathrm{M}^{+} \mathrm{OH}^{-} \mathrm{AEM}$ at $50^{\circ} \mathrm{C}$ in liquid water were estimated to be 17,14 , and $13 \mathrm{mS} \mathrm{cm}^{-1}$, respectively, with all AEMs exhibiting the same theoretical IEC of $1.8 \mathrm{mmol} \mathrm{g}^{-1}$. The MEAs were fabricated with lead

(b)
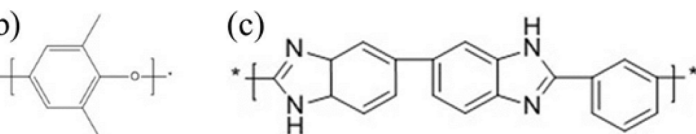

Fig. 2. Chemical structures of example homogenous AEMs: (a) polysulfone (PSF), (b) poly(2,6-dimethyl-p-phylene) oxide (PPO), and (c) polybenzimidazole (PBI). 
ruthenate pyrochlore and Pt black catalysts for the OER and HER, respectively, and the water electrolysis was performed using ultra pure water at $50^{\circ} \mathrm{C}$. The MEA utilizing the PSF-TMA ${ }^{+} \mathrm{OH}^{-}$membrane exhibited the highest current density, which was estimated to be about approximately $350 \mathrm{~mA} \mathrm{~cm}^{-2}$ at $1.8 \mathrm{~V}$ from its polarization curve. By contrast, the MEAs based on PSF-ABCO ${ }^{+} \mathrm{OH}^{-}$and PSF- $1 \mathrm{M}^{+} \mathrm{OH}^{-}$membranes both exhibited a current density of approximately $200 \mathrm{~mA} \mathrm{~cm}^{-2}$ at $1.8 \mathrm{~V}$, as shown in Fig. 3 . Three repeat polarization curve measurements showed short-term performance degradation in the PSF-TMA ${ }^{+} \mathrm{OH}^{-}$-membrane based MEA, with the high-frequency resistance (HFR) gradually increasing from 0.60 to $1.67 \Omega \mathrm{cm}^{2}$. The authors proved experimentally that the short-term performance degradation is caused mainly by the formation of carbonate anions as a result of $\mathrm{CO}_{2}$ intrusion. They also performed long-term operation tests using a constant current density of $200 \mathrm{~mA} \mathrm{~cm}^{-2}$ at $50^{\circ} \mathrm{C}$, and the MEA based on the PSF-TMA ${ }^{+} \mathrm{OH}^{-}$membrane exhibited the best performance. The cell voltage increased from 1.6 to $2.4 \mathrm{~V}$ over $6 \mathrm{~h}$ of cell operation, which was attributed to the degradation of the membrane backbone using nuclear magnetic resonance (NMR) spectroscopy. No functional group degradation was observed in this system [90].

\subsection{Polyphenylene Oxide-based AEMs}

PPO displays a better stability in alkaline media than PSF [99] and can be easily functionalized with various cationic groups [100-102]. These properties make it a good candidate for anion conducting polymer electrolytes. In order to increase the ionic conductivity and stability of AEMs under high $\mathrm{pH}$ conditions, Parrondo et al. developed PPO-based AEMs functionalized with $\mathrm{TMA}^{+}$or $\mathrm{ABCO}^{+}$groups and compared their initial performance and cell voltages during constant current operation at $100 \mathrm{~mA} \mathrm{~cm}^{-2}$ [91]. The authors also analyzed in detail the degradation mechanism of these AEMs during cell operation. The $\mathrm{TMA}^{+}$- and $\mathrm{ABCO}^{+}$-functionalized PPO membranes exhibited higher ionic conductivities than PSF [90] at $50^{\circ} \mathrm{C}$ in water, with values of approximately 44 (theoretical IEC of $2.1 \mathrm{mmol} \mathrm{g}^{-1}$ ) and $42 \mathrm{mS} \mathrm{cm}^{-1}$ (theoretical IEC of $1.9 \mathrm{mmol} \mathrm{g}^{-1}$ ), respectively [103]. For the single cell study, the MEAs were prepared by assembling a membrane with gas diffusion electrodes coated with $\mathrm{IrO}_{2}$ and Pt black electrocatalysts for the OER and HER, respectively. The AEMWE cell was operated with ultrapure water at $50^{\circ} \mathrm{C}$. The higher ionic conductivity of the PPO-TMA ${ }^{+} \mathrm{OH}^{-}$membrane resulted in a higher initial performance (approximately $230 \mathrm{~mA} \mathrm{~cm}^{-2}$ at $1.8 \mathrm{~V}$ ) compared to PPO$\mathrm{ABCO}^{+} \mathrm{OH}^{-}$membrane (approximately $60 \mathrm{~mA} \mathrm{~cm}^{-2}$ at $1.8 \mathrm{~V}$ ), as shown in Fig. $4 \mathrm{a}$. The cell voltage increased in comparison with the initial cell voltage during the continued constant current operation, as shown in Fig. 4b. Additionally, the HFR and chargetransfer resistance of both cells were greater after cell operation when compared to the initial values, as shown in Fig. 4c. Although no degradation in AEM
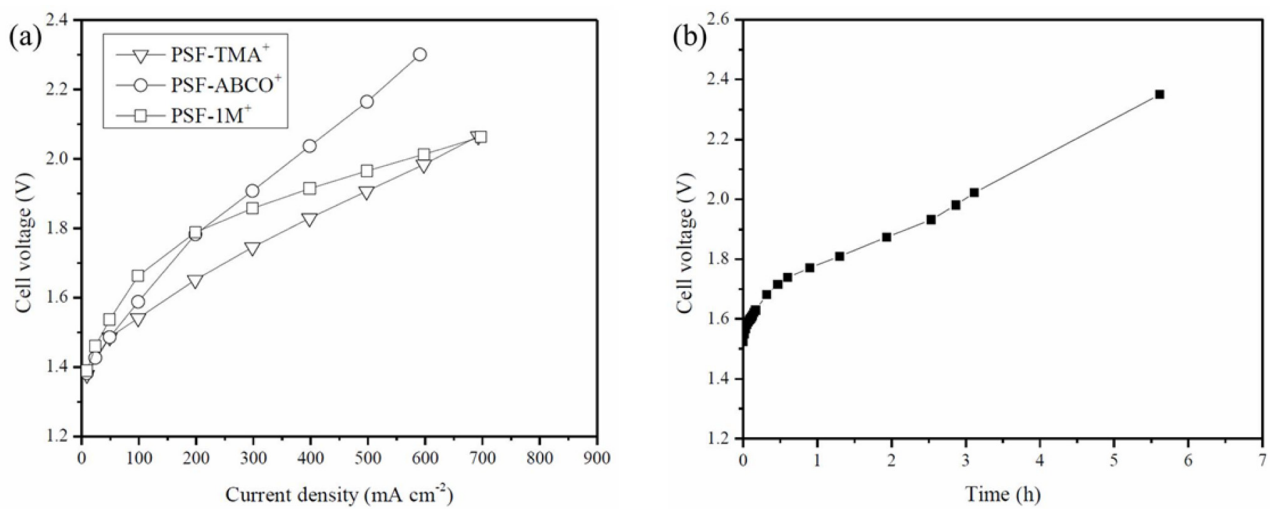

Fig. 3. (a) Polarization curves for PSF membranes functionalized with various cationic groups. The current density was increased from 10 to $700 \mathrm{~mA} \mathrm{~cm}{ }^{-2}$. (b) Durability test for PSF-TMA $\mathrm{OH}^{-}$MEA at a constant current density of $200 \mathrm{~mA}$ $\mathrm{cm}^{-2}$ at $50^{\circ} \mathrm{C}$ using ultrapure water. The figures were reproduced with permission from ref. [90]. Copyright 2014 Royal Society of Chemistry. 

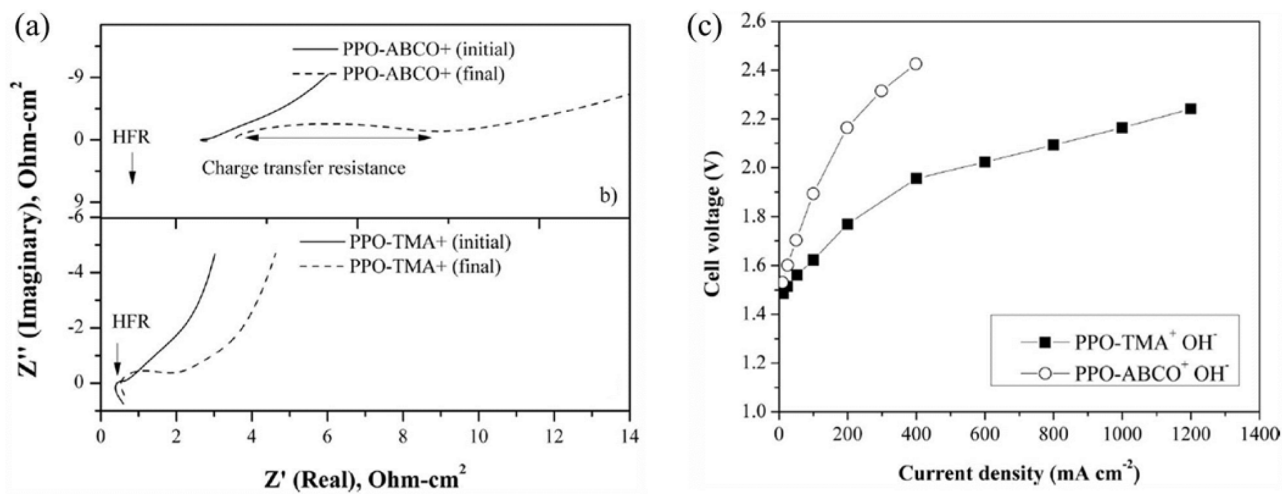

(b)

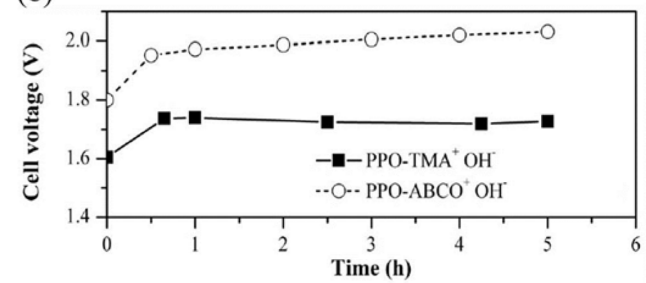

Fig. 4. (a) Initial polarization curves for an AEMWE cell utilizing an MEA with a PPO membrane functionalized with either $\mathrm{TMA}^{+}$or $\mathrm{ABCO}^{+}$groups. Performance (b) and impedance (c) of the cells determined from long-term stability tests performed at a constant current density of $100 \mathrm{~mA} \mathrm{~cm}^{-2}$ and $50^{\circ} \mathrm{C}$ using water. The figures were reproduced with permission from ref. [91]. Copyright 2014 Electrochemical Society.

functional groups was observed using NMR spectroscopy, catalyst particle loss was detected. This loss was attributed to poor adherence that was caused by the loss of binder in the electrode. Thus, the binder loss is the cause for the increased HFR, charge-transfer resistance, and cell voltage during operation [91].

\subsection{Polybenzimidazole-based AEMs}

Aili et al. measured the initial performance of AEMWE cells containing three different $\mathrm{KOH}-$ doped PBI membranes: untreated PBI (linear PBI), cross-linked PBI, and thermally treated PBI (thermally cured PBI). Moreover, the authors analyzed the degradation mechanism of the PBI membranes by measuring their thermo-oxidative stabilities [92]. The neutral PBI-based AEMs possess high chemical, thermal $\left(\mathrm{T}_{\mathrm{g}}=425-436^{\circ} \mathrm{C}\right)$, and mechanical stabilities [51] and can be rendered anion-conducting by doping with $\mathrm{KOH}$. Unlike the membranes that utilize quaternary ammonium and imidazolium groups for anion conduction, PBI-based AEMs do not display degradation of cationic functional groups mediated by the hydroxyl ion attack via direct nucleophilic displacement and Hofmann-elimination reactions [104]. The cross-linked and cured cross-linked membranes were prepared by thermally treating a PBI membrane at 280 and $350^{\circ} \mathrm{C}$, respectively, under $\mathrm{N}_{2}$ atmosphere, with a cross-linking agent, $p$-xylene dibromide, added to control the degree of cross-linking to $13 \%$. The MEAs were fabricated by sandwiching the membranes between polished nickel plates and the AEMWE cell tests were performed at $80^{\circ} \mathrm{C}$ using a $30 \mathrm{wt} . \% \mathrm{KOH}$ solution. Lastly, membrane aging tests were carried out by storing the membranes in a 25 wt. $\% \mathrm{KOH}$ solution at $85^{\circ} \mathrm{C}$ for 116 days and observing the polymer degradation. The conductivities of a commercial membrane $\left(\right.$ Zirfon $\left.^{\mathbb{R}}\right)$ and the linear, cross-linked, and thermally cured PBI membranes were determined to be approximately 77 , 24,20 , and $26 \mathrm{mS} \mathrm{cm}^{-1}$, respectively. In contrast to the results of conductivity tests, the MEA based on the cross-linked membrane exhibited the best single cell performance (approximately $63 \mathrm{~mA} \mathrm{~cm}^{-2}$ at $1.8 \mathrm{~V}$ ), while the MEAs based on the commercial membrane, linear PBI membrane, and thermally cured PBI membrane exhibited current densities of approximately 14,14 , and $27 \mathrm{~mA} \mathrm{~cm}^{-2}$, respectively, at the same voltage, as shown in Fig. 5a. During the 

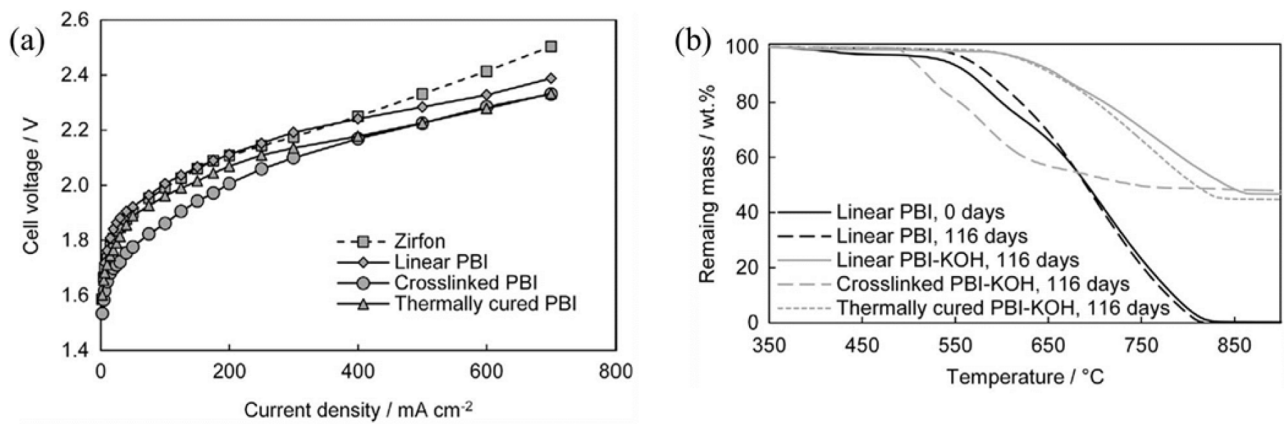

Fig. 5. (a) Polarization curves determined for an AEMWE cell utilizing processed PBI membranes at $80^{\circ} \mathrm{C}$ with a 30 wt.\% $\mathrm{KOH}$ solution as both the anode and cathode electrolyte. (b) PBI membrane aging tests conducted at $85^{\circ} \mathrm{C}$ for 116 days. The figures were reprinted with permission from ref. [92]. Copyright 2013 Elsevier.
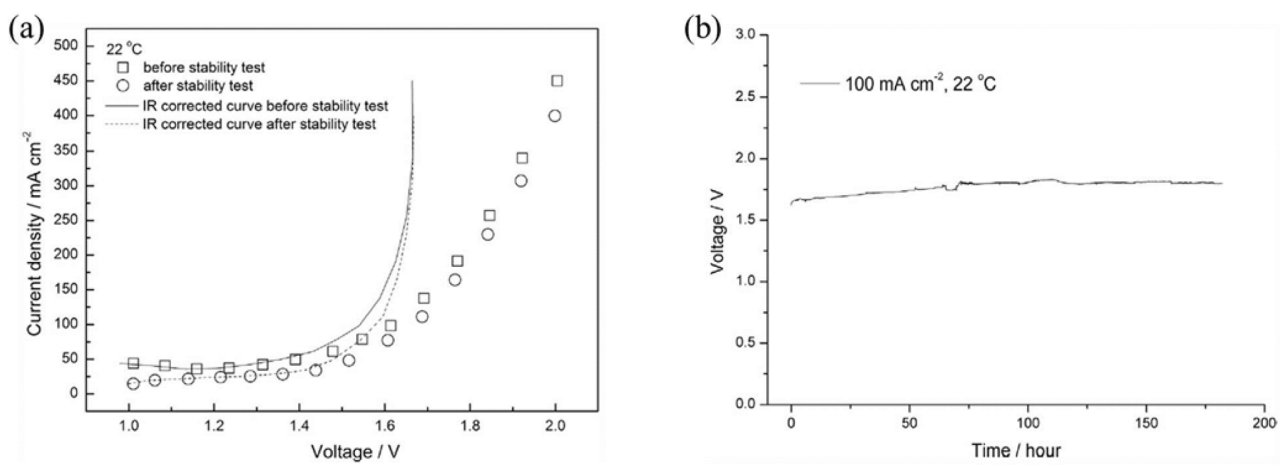

Fig. 6. (a) Polarization curves for an RCM-based MEA, where the RCM consists of a porous PTFE membrane filled a QPDTB ionomer, before and after stability testing. (b) AEMWE cell performance determined from stability testing at 100 $\mathrm{mA} \mathrm{cm}{ }^{-2}$ constant current density operation and $22^{\circ} \mathrm{C}$. The figures were reprinted with permission from ref. [96]. Copyright 2014 Elsevier.

membrane aging tests, polymer degradation was found to occur via backbone hydrolysis on the $\mathrm{C} 2$ position of benzimidazole, with the consequent molecular weight decrease during water electrolysis resulting in performance decline (Fig. 5b). Modification of the PBI-based polymer backbone was suggested as a way of further improving its long term stability [92].

Diaz et al. conducted AEMWE cell tests using linear (untreated) and cross-linked ABPBI (poly[2,5benzimidazole]) membranes doped with a $\mathrm{KOH}$ solution [50]. The cross-linking process was adopted to produce membranes with improved chemical, thermal, and mechanical stabilities relative to those of the untreated membrane. The cross-linked ABPBI membrane was prepared by benzoxazine polymerization followed by thermal treatment of the membrane at $180^{\circ} \mathrm{C}$ for $10 \mathrm{~h}$. The MEAs were fabricated by attaching Ni-foam electrodes directly onto the membranes for both the anode and cathode. The performance of each MEA was evaluated at 50 and $70^{\circ} \mathrm{C}$ in an AEMWE cell. The cross-linked membrane exhibited a higher ionic conductivity $\left(18 \mathrm{mS} \mathrm{cm}^{-1}\right)$ than the non-cross-linked linear membrane $\left(17 \mathrm{mS} \mathrm{cm}^{-1}\right)$. The MEAs based on the cross-linked and linear ABPBI membranes exhibited similar current densities of approximately $53 \mathrm{~mA} \mathrm{~cm}^{-2}$ at $1.8 \mathrm{~V}$ during cell operation at $50^{\circ} \mathrm{C}$ in a $1.9 \mathrm{M} \mathrm{KOH}$ solution. Both the cross-linked (approximately $89 \mathrm{~mA} \mathrm{~cm}^{-2}$ at $1.8 \mathrm{~V}$ ) and linear (approximately $80 \mathrm{~mA} \mathrm{~cm}^{-2}$ at $1.8 \mathrm{~V}$ ) ABPBI membrane based MEAs exhibited significantly improved performance at $70^{\circ} \mathrm{C}$ in a $3.0 \mathrm{M}$ $\mathrm{KOH}$ solution when compared to the MEA based on the commercial membrane (Zirfon ${ }^{\circledR}$ ) (approximately $47 \mathrm{~mA} \mathrm{~cm}^{-2}$ at $\left.1.8 \mathrm{~V}\right)$.

\subsection{Reinforced Composite Membranes (RCMs)}

As a result of the difficulties in achieving both high 
ionic conductivity and chemical stability in AEMs through the introduction of different functional groups, reinforced composite membranes (RCMs) [96] and inorganic membranes [21] have been developed as alternatives with the potential to attain both ionic conductivity and stability, and subsequently tested in AEMWE cells. Wu et al. evaluated the performance of an RCM-based MEA in an AEMWE single cell, where the RCM consisted of a porous PTFE-supported composite membrane filled with a polymethacrylate quaternary ammonium (QPDTB) ionomer [96]. The RCM-based AEM was ultra-thin $(30 \mu \mathrm{m})$ and prepared by filling the PTFE membrane pores with the QPDTB ionomer, which is an anion conductor developed by Wu et al. in a previous study [105]. The RCM exhibited an ionic conductivity of $34 \mathrm{mS} \mathrm{cm}^{-1}$ at $50^{\circ} \mathrm{C}$. The MEA was fabricated by spraying a catalyst slurry, consisting of the QPDTB ionomer mixed with $\mathrm{Cu}_{0.6} \mathrm{Mn}_{0.3} \mathrm{Co}_{2.1} \mathrm{O}_{4}$ and $\mathrm{Pt} / \mathrm{C}$ catalyst for the OER and HER, respectively, onto the RCM. The AEMWE cell stability was tested at $22^{\circ} \mathrm{C}$ using pure water. The current density of the MEA based on the RCM was approximately $200 \mathrm{~mA} \mathrm{~cm}^{-2}$ at $1.8 \mathrm{~V}$, as shown in Fig. 6a. It is difficult to compare the durability of this membrane with those of other developed membranes as a result of the low operating temperature $\left(22^{\circ} \mathrm{C}\right)$ employed in the stability test. Nevertheless, the durability test revealed a performance loss of $0.3 \%$ at $100 \mathrm{~mA} \mathrm{~cm}^{-2}$ over $120 \mathrm{~h}$ of AEMWE cell operation, as shown in Fig. 6b [96].

\subsection{Inorganic Membranes}

Inorganic material based layered double hydroxides (LDHs) have recently been developed for AEMWE cells and have displayed excellent stabilities and acceptable $\mathrm{OH}^{-}$ion conductivities during single cell testing in alkaline media [106]. The use LDHs can be advantageous not only because of their good chemical stability, which is derived from the absence of functional groups, but also because the typical synthesis of LDH membranes does not require the use of toxic or carcinogenic reagents $[21,106]$.

Zeng and Zhao monitored the long-term performance of an AEMWE cell containing a low-cost integrated inorganic MEA composed of an Mg-Al LDH membrane. This membrane was designed to overcome the challenges usually associated with AEMs, i.e., low ionic conductivity, chemical instabil-

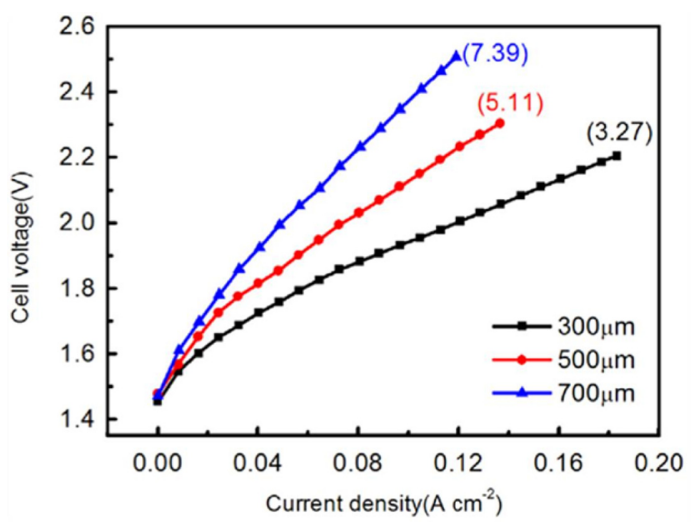

Fig. 7. Polarization curves for integrated inorganic MEAs containing Mg-Al LDH membranes of varying thickness. The cell was operated at $60^{\circ} \mathrm{C}$. The figure were reprinted with permission from ref. [21]. Copyright 2015 Elsevier.

ity, and chemical toxicity of the corresponding synthetic process [21]. The Mg-Al LDH membrane exhibited superior stability in an alkaline environment and high $\mathrm{OH}^{-}$ion conductivity $\left(7.7 \mathrm{mS} \mathrm{cm}^{-1}\right)$ under high relative humidity $(98 \%)$ at $60^{\circ} \mathrm{C}$. The MEAs were prepared using the Mg-Al LDH membrane and commercial OER $\left(\mathrm{CuCoO}_{\mathrm{x}}\right)$ and HER $\left(\mathrm{NiM} / \mathrm{CeO}_{2}-\mathrm{La}_{2} \mathrm{O}_{3} / \mathrm{C}\right)$ catalysts from Acta SpA. Polarization curves for the AEMWE cells fabricated with MEAs of varying thickness were measured at $50^{\circ} \mathrm{C}$ in $0.1 \mathrm{M} \mathrm{NaOH}$ solution, revealing current densities of approximately 60,38 , and $26 \mathrm{~mA} \mathrm{~cm}^{-2}$ at $1.8 \mathrm{~V}$ for the $300-, 500-$ and $700-\mu \mathrm{m}$-thick MEAs, respectively. The decrease in water splitting current density with increasing membrane thickness was caused by the increased ionic resistance, which was determined to be $3.25,5.11$, and $7.39 \Omega \mathrm{cm}^{2}$ for the $300-, 500-$, and $700-\mu \mathrm{m}$-thick MEAs, respectively, as shown in Fig. 7 [21].

\section{AEMWE Catalysts Tested in Single Cells}

The cost of water electrolysis employing AEMWE cells is lower when compared to the use of PEMWE cells. This decrease in cost stems from the fact that the alkaline electrolyzers employ inexpensive metals or metal oxides as the HER and OER catalysts while PEMWE requires costly PGM catalysts for the OER in order to ensure sufficiently high reaction rates in the acidic operating environment. The water splitting OER kinetics are more facile in an alkaline environ- 
ment than in an acidic environment. Thus, the OER has been widely studied under alkaline conditions to develop efficient non-PGM catalysts for cost effective water electrolysis. Many researchers developing these catalysts perform half-cell tests to evaluate the catalyst performance. However, although the halfcell test can give promising results, single cell tests are necessary in order to prove the utility of the catalysts in the MEA catalyst layer [88]. In this section, we review the research performed to date on the AEMWE single cell performance of non-PGM catalysts developed for the OER [52,93-95] and HER [63,107].

\subsection{OER Catalysts}

The OER kinetics are more sluggish than the HER kinetics and as a consequence, the performance of water electrolysis depends strongly on the OER (a four inner sphere electron transfer reaction). The OER activities of electrocatalysts are generally greater in higher $\mathrm{pH}$ solutions than in acidic or low $\mathrm{pH}$ solutions. As a result, non-noble metal oxides can be used as catalysts in AEMWE. Furthermore, waterelectrolysis systems operating under alkaline conditions are more durable and stable than those operating under acidic conditions. For example, the OER catalysts iridium oxide and ruthenium oxide exhibit dissolution rates during potential scanning that are ca. 700 and 600 times lower, respectively, in a $0.05 \mathrm{M}$ $\mathrm{NaOH}$ electrolyte than in acidic media [108]. Metal oxides are also often stable at high $\mathrm{pH}$ operating conditions as a result of the formation of a surface passivation layer [109].

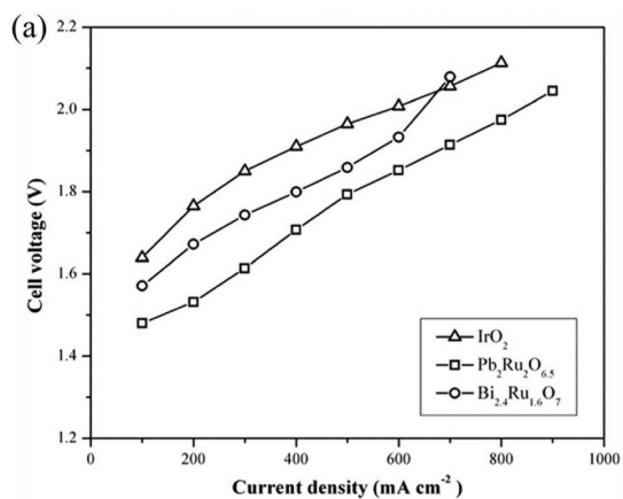

Parrondo et al. studied pyrochlore-structured metal oxides, which are highly active and stable OER catalysts. The authors performed AEMWE cell tests with $\mathrm{Pb}_{2} \mathrm{Ru}_{2} \mathrm{O}_{6.5}$ and $\mathrm{Bi}_{2.4} \mathrm{Ru}_{1.6} \mathrm{O}_{7}$ pyrochlores, which exhibit the highest OER mass and specific activities of all pyrochlore electrocatalysts [52]. These pyrochlore catalysts exhibited electronic conductivities of $120 \pm 30$ and $63 \pm 5 \mathrm{~S} \mathrm{~cm}^{-1}$ for $\mathrm{Pb}_{2} \mathrm{Ru}_{2} \mathrm{O}_{6.5}$ and $\mathrm{Bi}_{2.4} \mathrm{Ru}_{1.6} \mathrm{O}_{7}$, respectively, and their OER activities in the AEMWE cell were comparable with that of $\mathrm{IrO}_{2}$ (also tested in this study) [52]. In a half-cell evaluation, the OER mass activities of $\mathrm{Pb}_{2} \mathrm{Ru}_{2} \mathrm{O}_{6.5}$ and $\mathrm{Bi}_{2.4} \mathrm{Ru}_{1.6} \mathrm{O}_{7}$ pyrochlores were determined to be 202 and $10 \mathrm{Ag}^{-1}$, respectively, at $1.5 \mathrm{~V}_{\text {RHE }}$. The MEAs were subsequently fabricated by spraying catalyst ink ( $\mathrm{IrO}_{2}$ or the pyrochlores and Pt black for the OER and HER, respectively, mixed with an AEM binder) on a commercial AEM membrane (A201, Tokuyama Co.). The AEMWE cell was operated at $50^{\circ} \mathrm{C}$ and exhibited a current density of approximately 250 , 500 , and $400 \mathrm{~mA} \mathrm{~cm}^{-2}$ at $1.8 \mathrm{~V}_{\text {cell }}$ when employing $\mathrm{IrO}_{2}, \mathrm{~Pb}_{2} \mathrm{Ru}_{2} \mathrm{O}_{6.5}$, and $\mathrm{Bi}_{2.4} \mathrm{Ru}_{1.6} \mathrm{O}_{7}$ as the OER catalyst, respectively, as shown in Fig. 8a. The long-term AEMWE cell performance was tested using $\mathrm{Pb}_{2}$ $\mathrm{Ru}_{2} \mathrm{O}_{6.5}$, which showed the best initial performance. The cell exhibited a constant voltage of $1.75 \mathrm{~V}$ over $200 \mathrm{~h}$ of constant current operation at $200 \mathrm{~mA} \mathrm{~cm}^{-2}$ [52]. The catalytic activity showed a strong relationship with the strength of bonding between the B-site cation of the pyrochlore and the reaction intermediate species formed during the OER, as evidenced by the reaction paths studied at the surfaces of the pyrochlore.

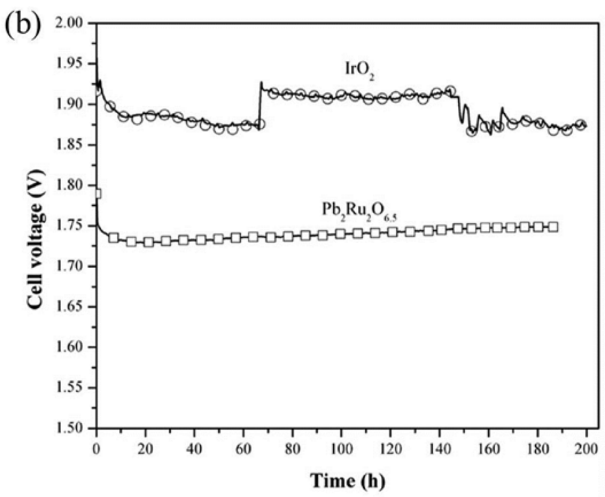

Fig. 8. (a) Polarization curves reported for MEAs prepared with pyrochlore OER electrocatalysts measured at $50^{\circ} \mathrm{C}$. (b) AEMWE cell long-term performance during operation at $200 \mathrm{~mA} \mathrm{~cm}{ }^{-2}$ and $35^{\circ} \mathrm{C}$ using a 1 wt. $\% \mathrm{KHCO}_{3}$ solution. The figures were reproduced with permission from ref. [52]. Copyright 2015 Royal Society of Chemistry. 
Seetharaman et al. studied a graphene oxide (GO) modified $\mathrm{NiO}$ electrode as an OER catalyst with enhanced electron conductivity and catalytic activity, and evaluated its initial performance and durability in an AEMWE cell [93]. A ternary Ni alloy was electrochemically deposited onto a nickel foam, followed by heat treatment at $350-400^{\circ} \mathrm{C}$ to produce a $\mathrm{NiO}$ foam catalyst for the OER. GO was synthesized separately from purified graphite using the Hummers method and painted onto the $\mathrm{NiO}$ foam. A Selemion ${ }^{\mathrm{TM}} \mathrm{AMV}$ membrane (Asahi Glass Co. Ltd.) was used to prepare the MEAs and sandwiched between the Ni foam electrodes. The GO-coated NiO foam catalyst exhibited the highest OER current density when compared to the $\mathrm{Ni}$ foam and $\mathrm{NiO}$ foam. The AEMWE cell tests were performed using deionized water and various concentrations of alkaline reactant solution ( 0 $5.36 \mathrm{M})$ at different operating temperatures $\left(30-80^{\circ} \mathrm{C}\right)$. Increasing the concentration of the alkaline solution improved the initial cell performance, with current densities of approximately $65 \mathrm{~mA} \mathrm{~cm}^{-2}$ and $140 \mathrm{~mA}$ $\mathrm{cm}^{-2}$ observed for pure water and a $5.36 \mathrm{M}$ electrolyte solution, respectively, at $1.8 \mathrm{~V}$ and $30^{\circ} \mathrm{C}$. In addition, the current density increased in the $5.36 \mathrm{M} \mathrm{KOH}$ electrolyte at $1.8 \mathrm{~V}$ from 100 to $380 \mathrm{~mA} \mathrm{~cm}^{-2}$ when the operating temperature was increased from 30 to $80^{\circ} \mathrm{C}$. The stability tests were performed over $24 \mathrm{~h}$ using the $5.36 \mathrm{M} \mathrm{KOH}$ solution at a constant voltage of $1.9 \mathrm{~V}$. A stable current density of approximately $513 \mathrm{~mA} \mathrm{~cm}{ }^{-2}$ was obtained at $80{ }^{\circ} \mathrm{C}$ when the MEA with a GO-coated electrode was employed, which represents almost a two-fold increase relative to the current density obtained using the MEA with uncoated electrode [93]. Application of the GO coating reduced the electrode resistance and enhanced the contact between the membrane and the electrodes, which in turn resulted in improved cell performance.

$\mathrm{Wu}$ et al. used nanoparticles of a $\mathrm{Li}_{\mathrm{x}} \mathrm{Co}_{3-\mathrm{x}} \mathrm{O}_{4}$ ternary metal oxide as a non-precious metal OER catalyst [94]. Lithium shows the highest activity amongst the various binary cobalt oxides $\mathrm{M}_{\mathrm{z}} \mathrm{Co}_{3-\mathrm{x}} \mathrm{O}_{4}(\mathrm{M}=\mathrm{Li}$, $\mathrm{Ni}$, and $\mathrm{Cu}$ ) [110]. The catalytic activity was evaluated as a function of the lithium molar content and the catalyst that exhibited the highest electronic conductivity was tested in an AEMWE cell [94]. The $\mathrm{Li}_{\mathrm{x}} \mathrm{Co}_{3-\mathrm{x}} \mathrm{O}_{4}$ nanoparticles were prepared by thermal decomposition of a mixture of $\mathrm{LiCl} \cdot 2 \mathrm{H}_{2} \mathrm{O}$ and $\mathrm{CoCl}_{2} \cdot 6 \mathrm{H}_{2} \mathrm{O}$ in deionized water and ethanol. Incorporating $\mathrm{Li}$ in $\mathrm{Co}_{3} \mathrm{O}_{4}$ increased its electronic conductiv- ity by at least $\sim 20$-fold; however, no specific trend was observed on increasing the $\mathrm{Li}$ content in the $\mathrm{Li}_{\mathrm{x}}$ $\mathrm{Co}_{3-\mathrm{x}} \mathrm{O}_{4}$ nanoparticles. $\mathrm{Li}_{0.21} \mathrm{Co}_{2.79} \mathrm{O}_{4}$, which exhibited the best electronic conductivity $\left(2.1 \mathrm{~s} \mathrm{~cm}^{-1}\right)$ and OER current density (approximately $850 \mathrm{~mA} \mathrm{~cm}^{-1}$ at $650 \mathrm{mV}_{\mathrm{Hg} / \mathrm{HgO}}$ ) was tested in a single cell. The MEAs were fabricated by spraying the catalyst ink, i.e., a mixture of the ionomer and the catalyst, on the AEMs (polymethacrylate quaternary ammonium $\mathrm{OH}^{-}$membrane). A $2.5 \mathrm{mg} \mathrm{cm}^{-2}$ loading of $\mathrm{Li}_{0.21} \mathrm{Co}_{2.79} \mathrm{O}_{4}$ was used for the OER, while $2 \mathrm{mg} \mathrm{cm}^{-2}$ loading of $\mathrm{Ni}$ powder was used for the HER. The AEMWE cell exhibited a current density of approximately $40 \mathrm{~mA}$ $\mathrm{cm}^{-2}$ at $1.8 \mathrm{~V}$ using a deionized water feed at $45^{\circ} \mathrm{C}$ [94].

Wu et al. evaluated $\mathrm{Cu}_{\mathrm{x}} \mathrm{Mn}_{0.9-\mathrm{x}} \mathrm{Co}_{2.1} \mathrm{O}_{4}$ as a bifunctional catalyst by employing varying molar ratios of $\mathrm{Mn}$ to prepare $\mathrm{Mn}$ - and $\mathrm{Cu}$-doped cobaltite oxide and to improve its OER and oxygen reduction reaction (ORR) catalytic activity. $\mathrm{Cu}_{0.6} \mathrm{Mn}_{0.3} \mathrm{Co}_{0.21} \mathrm{O}_{4}$ exhibited the best OER performance and was therefore used to prepare MEAs, which were subsequently tested in a single cell configuration [95]. The catalyst was synthesized by addition of $\mathrm{NaNO}_{3}$ into a solution of $\mathrm{CuCl}_{2} \cdot 2 \mathrm{H}_{2} \mathrm{O}, \mathrm{MnCl}_{2} \cdot 4 \mathrm{H}_{2} \mathrm{O}$, and $\mathrm{CoCl}_{2} \cdot 6 \mathrm{H}_{2} \mathrm{O}$, followed by drying at $70^{\circ} \mathrm{C}$, and annealing at $400-500^{\circ} \mathrm{C}$ in air. The MEAs were prepared by spraying the catalyst slurry onto both sides of the membrane. In this case, the slurry was comprised of a mixture of the ionomer and the developed catalyst and $\mathrm{Pt} / \mathrm{C}$ catalyst for the OER and HER, respectively. When using the developed OER catalyst, a current density of approximately $60 \mathrm{~mA} \mathrm{~cm}^{-2}$ at $1.8 \mathrm{~V}$ was obtained with deionized water at $40^{\circ} \mathrm{C}$ [95].

\subsection{HER Catalysts}

The influence of non-PGM HER catalyst loading on AEMWE cell performance was investigated by Pavel et al. [107]. The anode-catalyst loading was set to $36 \mathrm{mg} \mathrm{cm}^{-2}$ and the cell performance was examined as a function of increasing cathode-catalyst loading. The MEAs were fabricated using a commercial AEM (A201, Tokuyama Co.) with $\mathrm{CuCoO}_{\mathrm{x}}$ (Acta 3030, Acta $\mathrm{SpA}$ ) and $\mathrm{Ni} /\left(\mathrm{CeO}_{2}-\mathrm{La}_{2} \mathrm{O}_{3}\right) / \mathrm{C}($ Acta 4030, Acta SpA) as the OER (anode) and HER (cathode) catalyst, respectively. The catalyst layers were prepared by mixing the corresponding catalyst with a PTFE binder. The mixtures were subsequently spread onto a porous $\mathrm{Ni}$ foam and sprayed onto a carbon 
(a)

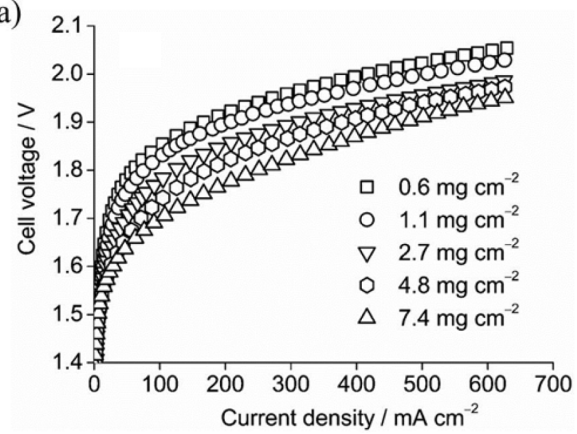

(b)

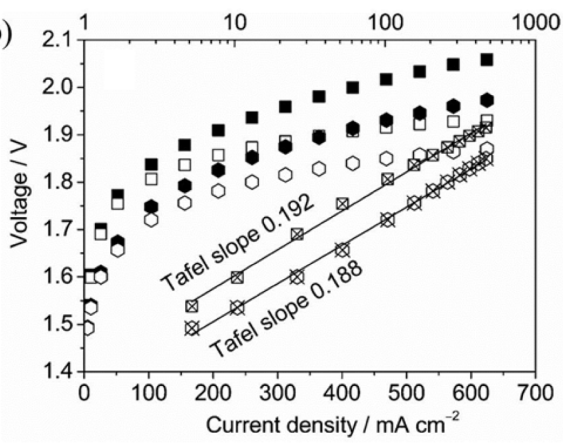

Fig. 9. (a) Polarization curves reported after $24 \mathrm{~h}$ of constant-current-density $\left(470 \mathrm{~mA} \mathrm{~cm}{ }^{-2}\right)$ cell operation with a 1 wt. $\%$ $\mathrm{K}_{2} \mathrm{CO}_{3}$ solution feed at $43^{\circ} \mathrm{C}$ as a function of HER-catalyst loading in the MEA. (b) Polarization curves before ohmicoverpotential correction (solid symbols) and after ohmic-overpotential correction (open symbols) for 0.6 (square symbols) and $4.8 \mathrm{mg} \mathrm{cm}^{-2} \mathrm{HER}$ catalyst loadings (hexagonal symbols). The figures were reproduced with permission from ref. [107]. Copyright 2014 Wiley-VCH.

cloth to prepare the anode and cathode, respectively. The HER-catalyst loading was varied from 0.6 to $7.4 \mathrm{mg} \mathrm{cm}^{-2}$ and the current density exhibited by the AEMWE cell increased with increasing HER catalyst loading from approximately 40 to $300 \mathrm{~mA} \mathrm{~cm}^{-2}$ at $1.8 \mathrm{~V}$, as shown in Fig. 9 [107].

Ahn et al. constructed an efficient HER electrode using an ultra-low Pt loading $\left(1.84 \mu \mathrm{g}_{\mathrm{Pt}} \mathrm{cm}^{-2}\right)$ and the MEA utilizing this electrode was tested in an AEMWE cell [63]. Typically, few $\mathrm{mg} \mathrm{cm}^{-2}$ [19] of $\mathrm{Pt}$ black have been used for HER catalysis in other studies. In this study, by contrast, electrodeposition was used to decrease the Pt loading by three orders of magnitude. Ni was first electrodeposited on carbon paper $(\mathrm{CP})$ in a $0.5 \mathrm{M} \mathrm{NiCl}_{2}$ solution by holding the $\mathrm{CP}$ at $-0.95 \mathrm{~V}_{\mathrm{SCE}}$ for $50 \mathrm{~s}$. Pt was subsequently coated on the Ni-coated $\mathrm{CP}$ using galvanic displacement in a $1 \mathrm{mM} \mathrm{K}_{2} \mathrm{PtCl}_{6}$ solution at various concentrations of $\mathrm{HCl}$ for $180 \mathrm{~s}$. The electrodeposition and galvanic displacement reactions produced ultra-thin catalyst layers on the $\mathrm{CP}$ gas diffusion layers (GDLs), which displayed a small ohmic resistance, fast mass transport, and high catalyst utilization. In half-cell measurements, the $\mathrm{Pt}-\mathrm{Ni} / \mathrm{CP}$ electrode exhibited higher HER activity $\left(-73.7 \mathrm{~mA} \mathrm{~cm}_{\mathrm{geo}}{ }^{-2}\right.$ at $\left.-0.70 \mathrm{~V}_{\mathrm{RHE}}\right)$ than the bare $\mathrm{Ni} / \mathrm{CP}$ electrode $(-59.4$ $\mathrm{mA} \mathrm{cm}{ }_{\text {geo }}{ }^{-2}$ at $\left.-0.70 \mathrm{~V}_{\mathrm{RHE}}\right)$. For the single-cell study, the MEAs were prepared by sandwiching a commercial membrane (A201, Tokuyama Co.) between Ni/ CP (OER electrode) and Pt-Ni/CP (HER electrode). The AEMWE cell performance was evaluated at $50^{\circ} \mathrm{C}$ with a $1.0 \mathrm{M} \mathrm{KOH}$ solution supplied only to the cathode. When using the Pt-Ni/CP as the HER electrode, the current densities at $1.8 \mathrm{~V}$ were approximately 180 and $210 \mathrm{~mA} \mathrm{~cm}^{-2}$ at 50 and $70^{\circ} \mathrm{C}$, respectively, and these values are by 100 and $80 \mathrm{~mA}$ $\mathrm{cm}^{-2}$ higher than the current density achieved using the Ni/CP electrode [63].

\section{Conclusions}

Herein, electrocatalysts and polymer electrolyte membranes used in AEMWE single cells have been reviewed. In order to achieve the demanding performance standards required for practical AEMWE, the membrane should conduct $\mathrm{OH}^{-}$ions efficiently and be sufficiently chemically stable under alkaline conditions ( $\mathrm{pH}$ 13-14). Non-PGM catalysts used for OER and HER in an alkaline environment have also been extensively studied in an attempt to enhance their kinetics and stability. AEMWE cells utilizing cheap membranes and non-PGM catalysts are great potential candidates for satisfying the 2020 Department of Energy (DOE) target of $\$ 2.30 / \mathrm{kg}_{\mathrm{H} 2 \mathrm{O}}$ and $43 \mathrm{kWh} / \mathrm{kg}_{\text {stack }}$. However, the performance of state-ofthe-art AEMWE cells (approximately $530 \mathrm{~mA} \mathrm{~cm}^{-2}$ at $1.8 \mathrm{~V})$ and their reported durability $(1000 \mathrm{~h})$ are currently still insufficient to meet industrial needs. In order to advance the AEMWE technology, further studies focusing on MEAs that utilize the developed electrocatalysts and polymer electrolyte membranes are essential in order to attain improved catalyst utilization and mass transport in practical-device operation as well as to improve the electrode durability. 


\section{Acknowledgement}

This work was supported by the New and Renewable Energy Core Technology Program of the Korea Institute of Energy Technology Evaluation and Planning (KETEP) funded by the Ministry of Trade, Industry and Energy, Republic of Korea (MOTIE, Grant No. 20143010031770). This study was also financially supported by the KIST through the Institutional Project.

\section{References}

[1] A.B. Rao, E.S. Rubin, Environ. Sci. Technol., 2002, 36(20), 4467-4475.

[2] Hoffert, Martin I., et al., Science, 2002, 298(5595), 981987.

[3] J.M. Reilly, The Bridge, 2015, 45(2), 6-15.

[4] R. Jackson, P. Friedlingstein, J. Canadell, R. Andrew, The Bridge, 2015, 45(2), 16-21.

[5] S. Kerdsuwan, K. Laohalidanond, Energy Procedia, 2015, 79, 125-130.

[6] A. Züttel, Mitigation and Adaptation Strategies for Global Change, 2007, 12(3), 343-365.

[7] K. Christopher, R. Dimitrios, Energy Environ.Sci., 2012, 5(5, 6640-6651.

[8] M. Melaina, M. Penev, D. Heimiller, NREL technical report, 2013, NREL/TP-5400-55626.

[9] G. Collodi, F. Wheeler, Chem.Eng.Trans., 2010, 19, 3742.

[10] G. Simbolotti, IEA Energy Technology Essentials, IEA, 2007.

[11] W. Kreuter, H. Hofmann, Int. J.Hydrogen Energy, 1998, 23(8), 661-666.

[12] K. Zeng, D. Zhang, Prog. Energy Combust. Sci., 2010, 36(3), 307-326.

[13] J.D. Holladay, J. Hu, D.L. King, Y. Wang, Catal.Today, 2009, 139(4), 244-260.

[14] P. Millet, F. Andolfatto, R. Durand, Int. J. Hydrogen Energy, 1996, 21, 87-93.

[15] A. Goñi-Urtiaga, D. Presvytes, K. Scott, Int. J. Hydrogen Energy, 2012, 37(4), 3358-3372.

[16] K. Ito, T. Sakaguchi, Y. Tsuchiya, Polymer Electrolyte Membrane Water Electrolysis, in: Hydrogen Energy Engineering, Springer, (2016) 143-149.

[17] J.R. McKone, N.S. Lewis, H.B. Gray, Chem.Mater, 2013, 26(1), 407-414.

[18] InfoMine Inc. (2017) Retrieved March, 2017, from http:/ /www.infomine.com/ investment/metal-prices.

[19] Y. Leng, G. Chen, A.J. Mendoza, T.B. Tighe, M.A. Hickner, C.-Y. Wang, J. Am. Chem. Soc., 2012, 134(22), 9054-9057.

[20] V.K. Puthiyapura, S. Pasupathi, H. Su, X. Liu, B. Pollet, K. Scott, Int. J. Hydrogen Energy, 2014, 39(5), 1905-1913.

[21] L. Zeng, T.S. Zhao, Nano Energy, 2015, 11, 110-118.
[22] D. Lu, D. Li, L. Wen, L. Xue, J. Membr.Sci., 2017, 533, 210-219.

[23] H. Wu, W. Jia, Y. Liu, J. Mater. Sci., 2017, 52(3), 17041716.

[24] X. Gong, X. Yan, T. Li, X. Wu, W. Chen, S. Huang, Y. Wu, D. Zhen, G. He, J. Membr. Sci., 2017, 523, 216-224.

[25] X. He, X. Jiang, Z. Wang, Y. Deng, Z. Han, Y. Yang, D. Chen, Polym. Eng. Sci., 2017 (Browse Early View Article, DOI: 10. 1002/pen.24524).

[26] WANG, Lianqin, et al., Green Chemistry, 2017, 19(3), 831-843.

[27] J. Li, X. Yan, X. Ruan, W. Zheng, G. He, J. Dai, R. Deng, Polym. Mater. Sci. Eng., 2016, 32, 38-42.

[28] Z. Hu, W. Tang, D. Ning, X. Zhang, H. Bi, S. Chen, Fuel Cells, 2016, 16(5), 557-567.

[29] C. Wang, B. Lin, G. Qiao, L. Wang, L. Zhu, F. Chu, T. Feng, N. Yuan, J. Ding, Mater. Lett., 2016, 173, 219222.

[30] T. Bayer, B.V. Cunning, R. Selyanchyn, T. Daio, M. Nishihara, S. Fujikawa, K. Sasaki, S.M. Lyth, J. Membr.Sci., 2016, 508, 51-61.

[31] T. Feng, B. Lin, S. Zhang, N. Yuan, F. Chu, M.A. Hickner, C. Wang, L. Zhu, J. Ding, J. Membr.Sci., 2016, 508, 7-14.

[32] A.G. Wright, J. Fan, B. Britton, T. Weissbach, H.F. Lee, E.A. Kitching, T.J. Peckham, S. Holdcroft, Energy Environ. Sci., 2016, 9(6), 2130-2142.

[33] B. Shi, Y. Li, H. Zhang, W. Wu, R. Ding, J. Dang, J. Wang, J. Membr.Sci., 2016, 498, 242-253.

[34] Z. Li, W. Wang, Y. Chen, C. Xiong, G. He, Y. Cao, H. Wu, M.D. Guiver, Z. Jiang, J. Mater. Chem. A, 2016, 4(6), 2340-2348.

[35] C. Yang, S. Wang, W. Ma, S. Zhao, Z. Xu, G. Sun, J. Mater. Chem. A, 2016, 4(10), 3886-3892.

[36] D. Lu, L. Wen, L. Xue, RSC $A d v$., 2016, 6(75), 7143171440.

[37] J. Li, X. Yan, Y. Zhang, B. Zhao, G. He, RSC Adv, 2016, 6(63), 58380-58386.

[38] P. Papakonstantinou, V. Deimede, RSC Adv, 2016, 6(115), 114329-114343.

[39] Y. Yang, N. Sun, P. Sun, L. Zheng, RSC $A d v$., 2016, 6(30), 25311-25318.

[40] F. Song, Y. Fu, Y. Gao, J. Li, J. Qiao, X.D. Zhou, Y. Liu, Electrochim. Acta, 2015, 177, 137-144.

[41] Y. Gao, F. Song, J. Qiao, S. Chen, X. Zhao, J. Zhang, Electrochim. Acta, 2015, 177, 201-208.

[42] L. Wu, Q. Pan, J.R. Varcoe, D. Zhou, J. Ran, Z. Yang, T. Xu, J. Membr. Sci., 2015, 490, 1-8.

[43] C. Yang, S. Wang, W. Ma, L. Jiang, G. Sun, J. Membr. Sci., 2015, 487, 12-18.

[44] C. Yang, S. Wang, W. Ma, L. Jiang, G. Sun, J. Mater. Chem. A, 2015, 3(16), 8559-8565.

[45] S.D. Poynton, J.R. Varcoe, Solid State Ionics, 2015, 277, 38-43.

[46] W.-H. Lee, A.D. Mohanty, C. Bae, ACS Macro Lett., 2015, 4(4), 453-457. 
[47] J. Fang, Y. Wu, Y. Zhang, M. Lyu, J. Zhao, Int. J. Hydrogen Energy, 2015, 40(36), 12392-12399.

[48] S. Chen, Y. Song, F. Song, X. Zhao, J. Qiao, X.-D. Zhou, ECS Trans., 2015, 66(3), 111-116.

[49] Z. Li, Z. Jiang, H. Tian, S. Wang, B. Zhang, Y. Cao, G. He, Z. Li, H. Wu, J. Power Sources, 2015, 288, 384392.

[50] L.A. Diaz, J. Hnát, N. Heredia, M.M. Bruno, F.A. Viva, M. Paidar, H.R. Corti, K. Bouzek, G.C. Abuin, J. Power Sources, 2016, 312, 128-136.

[51] G. Merle, M. Wessling, K. Nijmeijer, J. Membr. Sci., 2011, 377(1), 1-35.

[52] J. Parrondo, M. George, C. Capuano, K.E. Ayers, V. Ramani, J. Mater. Chem. A, 2015, 3(20), 10819-10828.

[53] T. Zhan, X. Liu, S. Lu, W. Hou, Appl. Catal., B, 2017, 205, 551-558.

[54] J. Yang, T. Fujigaya, N. Nakashima, Sci. Rep., 2017, 7, 45384-45392.

[55] S. Dutta, C. Ray, Y. Negishi, T. Pal, ACS Appl. Mater. Interfaces, 2017, 9, 8134-8141.

[56] Z.-Y. Yu, Y. Duan, M.-R. Gao, C.-C. Lang, Y.-R. Zheng, S.-H. Yu, Chemical Science, 2017, 8(2), 968-973.

[57] Y. Jin, X. Yue, C. Shu, S. Huang, P.K. Shen, J. Mater. Chem. A, 2017, 5(6), 2508-2513.

[58] X. Chen, G. Zeng, T. Gao, Z. Jin, Y. Zhang, H. Yuan, D. Xiao, Electrochem. Commun., 2017, 74, $42-47$.

[59] Y. Fang, X. Li, S. Zhao, J. Wu, F. Li, M. Tian, X. Long, J. Jin, J. Ma, $R S C A d v$., 2016, 6(84), 80613-80620.

[60] J. Wang, K. Li, H.x. Zhong, D. Xu, Z.l. Wang, Z. Jiang, Z.j. Wu, X.b. Zhang, Angew. Chem. Int. Ed., 2015, 54(36), 10530-10534.

[61] B. Jović, U. Lačnjevac, V. Jović, N. Krstajić, J. Electroanal. Chem., 2015, 754, 100-108.

[62] P. Hosseini-Benhangi, M.A. Garcia-Contreras, A. Alfantazi, E.L. Gyenge, J. Electrochem. Soc., 2015, 162(12), F1356-F1366.

[63] S.H. Ahn, S.J. Yoo, H.-J. Kim, D. Henkensmeier, S.W. Nam, S.-K. Kim, J.H. Jang, Appl. Catal., B, 2016, 180, 674-679.

[64] W. Badawy, H. Nady, G.A. El-Hafez, J. Alloys Compd., 2017, 699, 1146-1156.

[65] R. Solmaz, A. Salcı, H. Yüksel, M. Doğrubaş, G. Kardaş, Int. J. Hydrogen Energy, 2017, 42(4), 2464-2475.

[66] P. Jiang, Y. Yang, R. Shi, G. Xia, J. Chen, J. Su, Q. Chen, J. Mater. Chem. A, 2017, 5(11), 5475-5485.

[67] M. Gao, C. Yang, Q. Zhang, Y. Yu, Y. Hua, Y. Li, P. Dong, Electrochim. Acta, 2016, 215, 609-616.

[68] B. Zhang, H.-H. Wang, H. Su, L.-B. Lv, T.-J. Zhao, J.M. Ge, X. Wei, K.-X. Wang, X.-H. Li, J.-S. Chen, Nano Res., 2016, 9(9), 2606-2615.

[69] C. González-Buch, I. Herraiz-Cardona, E.M. Ortega, S. Mestre, V. Pérez-Herranz, Int. J. Hydrogen Energy, 2016, 41(2), 764-772.

[70] R. Kavian, S.-I. Choi, J. Park, T. Liu, H.-C. Peng, N. Lu, J. Wang, M.J. Kim, Y. Xia, S.W. Lee, J. Mater. Chem. A, 2016, 4(32), 12392-12397.
[71] B. Pierozynski, T. Mikolajczyk, Electrocatalysis, 2016, 7(2), 121-126.

[72] Y. Liu, G-D. Li, L. Yuan, L. Ge, H. Ding, D. Wang, X. Zou, Nanoscale, 2015, 7(7), 3130-3136.

[73] B. Jović, V. Jović, U. Lačnjevac, L. Gajić-Krstajić, N. Krstajić, Int. J. Hydrogen Energy, 2015, 40(33), 1048010490.

[74] M. Wang, Z. Wang, X. Yu, Z. Guo, Int. J. Hydrogen Energy, 2015, 40(5), 2173-2181.

[75] L. Han, S. Dong, E. Wang, Adv. Mater, 2016, 28, 92669291.

[76] B. Bladergroen, H. Su, S. Pasupathi, V. Linkov, Overview of Membrane Electrode Assembly Preparation Methods for Solid Polymer electrolyte Electrolyzer, in: D.J. Kleperis (Ed.) Electrolysis, InTech, 2012.

[77] T. Suzuki, S. Tsushima, S. Hirai, Int. J. Hydrogen Energy, 2011, 36(19), 12361-12369.

[78] K.-H. Kim, K.-Y. Lee, H.-J. Kim, E. Cho, S.-Y. Lee, T.H. Lim, S.P. Yoon, I.C. Hwang, J.H. Jang, Int. J. Hydrogen Energy, 2010, 35(5), 2119-2126.

[79] S. Jeon, J. Lee, G.M. Rios, H.-J. Kim, S.-Y. Lee, E. Cho, T.-H. Lim, J. Hyun Jang, Int. J. Hydrogen Energy, 2010, 35(18), 9678-9686.

[80] M.K. Cho, H.-Y. Park, S.Y. Lee, B.-S. Lee, H.-J. Kim, D. Henkensmeier, S.J. Yoo, J.Y. Kim, J. Han, H.S. Park, Y.-E. Sung, J.H. Jang, Electrochim. Acta, 2017, 224, 228-234.

[81] D.S. Hwang, C.H. Park, S.C. Yi, Y.M. Lee, Int. J. Hydrogen Energy, 2011, 36(16), 9876-9885.

[82] S. Kamarajugadda, S. Mazumder, J. Power Sources, 2008, 183(2), 629-642.

[83] Y. Qiu, H. Zhang, H. Zhong, F. Zhang, Int. J. Hydrogen Energy, 2013, 38(14), 5836-5844.

[84] M. Yazdanpour, A. Esmaeilifar, S. Rowshanzamir, Int. J. Hydrogen Energy, 2012, 37(15), 11290-11298.

[85] A. Therdthianwong, P. Manomayidthikarn, S. Therdthianwong, Energy, 2007, 32(12), 2401-2411.

[86] O. Okur, Ç. İyigün Karadağ, F.G. Boyacı San, E. Okumuş, G. Behmenyar, Energy, 2013, 57, 574-580.

[87] Z.X. Liang, T.S. Zhao, C. Xu, J.B. Xu, Electrochim. Acta, 2007, 53(2), 894-902.

[88] J. Zhang, H. Zhang, J. Wu, J. Zhang, Chapter 3 Techniques for PEM Fuel Cell Testing and Diagnosis, in: Pem Fuel Cell Testing and Diagnosis, Elsevier, Amsterdam, 2013.

[89] L. Xiao, S. Zhang, J. Pan, C. Yang, M. He, L. Zhuang, J. Lu, Energy Environ. Sci., 2012, 5(7), 7869-7871.

[90] J. Parrondo, C.G. Arges, M. Niedzwiecki, E.B. Anderson, K.E. Ayers, V. Ramani, RSC Adv, 2014, 4(19), 9875-9879.

[91] J. Parrondo, V. Ramani, J. Electrochem. Soc., 2014, 161(10), F1015-F1020.

[92] D. Aili, M.K. Hansen, R.F. Renzaho, Q. Li, E. Christensen, J.O. Jensen, N.J. Bjerrum, J. Membr. Sci., 2013, 447, 424-432.

[93] S. Seetharaman, R. Balaji, K. Ramya, K.S. 
Dhathathreyan, M. Velan, Int. J. Hydrogen Energy, 2013, 38(35), 14934-14942.

[94] X. Wu, K. Scott, Int. J. Hydrogen Energy, 2013, 38(8), 3123-3129.

[95] X. Wu, K. Scott, J. Power Sources, 2012, 206, 14-19.

[96] X. Wu, K. Scott, F. Xie, N. Alford, J. Power Sources, 2014, 246, 225-231.

[97] A. Abdelrasoul, H. Doan, A. Lohi, C.-H. Cheng, ChemBioEng Reviews, 2015, 2(1), 22-43.

[98] J. Pan, Y. Li, L. Zhuang, J. Lu, Chemical Communications, 2010, 46(45), 8597-8599.

[99] Varcoe, John R., et al., Energy Environ. Sci., 2014, 7(10), 3135-3191.

[100] N.T. Rebeck, Y. Li, D.M. Knauss, Journal of Polymer Science Part B: Polymer Physics, 2013, 51(24), 17701778.

[101] Z. Wang, J. Parrondo, V. Ramani, J. Electrochem. Soc., 2016, 163(8), F824-F831.

[102] K.H. Gopi, S.G. Peera, S.D. Bhat, P. Sridhar, S. Pitchumani, Int. J. Hydrogen Energy, 2014, 39(6), 2659-2668.
[103] C.G. Arges, L. Wang, J. Parrondo, V. Ramani, J. Electrochem. Soc., 2013, 160(11), F1258-F1274.

[104] Y.S. Li, T.S. Zhao, Int. J. Hydrogen Energy, 2012, 37(5), 4413-4421.

[105] X. Wu, K. Scott, J. Power Sources, 2012, 214, 124129.

[106] Y. Furukawa, K. Tadanaga, A. Hayashi, M. Tatsumisago, Solid State Ionics, 2011, 192(1), 185-187.

[107] C.C. Pavel, F. Cecconi, C. Emiliani, S. Santiccioli, A. Scaffidi, S. Catanorchi, M. Comotti, Angew. Chem. Int. Ed., 2014, 53(5), 1378-1381.

[108] S. Cherevko, S. Geiger, O. Kasian, N. Kulyk, J.-P. Grote, A. Savan, B.R. Shrestha, S. Merzlikin, B. Breitbach, A. Ludwig, K.J.J. Mayrhofer, Catal. Today, 2016, 262, 170-180.

[109] Z. Feng, W.T. Hong, D.D. Fong, Y.-L. Lee, Y. Yacoby, D. Morgan, Y. Shao-Horn, Acc. Chem. Res., 2016, 49(5), 966-973.

[110] I. Nikolov, R. Darkaoui, E. Zhecheva, R. Stoyanova, N. Dimitrov, T. Vitanov, J. Electroanal. Chem., 1997, 429(1-2), 157-168. 